\title{
DAMPAK SISTEM PEMBAYARAN SEWA KENDARAAN TRUCKING TERHADAP KEGIATAN OPERASIONAL PERUM DAMRI LOGISTIK
}

\section{IMPACT OFVEHICLE RENTAL PAYMENT SYSTEM TRUCKING ON OPERATIONAL ACTIVITIES PERUM DAMRI LOGISTIC}

\author{
Sylvira Ananda Azwar ${ }^{\text {a,1*}, ~ K e n c a n a ~ V e r a w a t i ~}{ }^{\mathbf{a}, \mathbf{2}}$, Meliana Safitri ${ }^{\mathbf{a}, \mathbf{3}}$, Anthony Costa ${ }^{\mathbf{b}, \mathbf{4}}$ \\ a Transportasi, Teknik Sipil, Universitas Negeri Jakarta, Jl. Rawamangun Muka, Jakarta Timur, Indonesia \\ b Teknik Sipil, Teknik, Universitas Sriwijaya, Indralaya, Sumatera Selatan \\ ${ }^{1 *}$ sylvira99@gmail.com ${ }^{2}$ kencanaverawati25@ gmail.com, ${ }^{3}$ melianasafitri04@gmail.com ${ }^{4}$ anthonycosta@ft.unsri.ac.id \\ *corresponding e-mail: sylvira99@gmail.com
}

\section{ABSTRACT}

This Research aims to find out the causes and impacts caused by delays in payment of trucking vehicle rentals at Perum DAMRI Logistik, especially on the company's operational activities. Data collection was carried out in 3 divisions in Perum DAMRI Logistics, namely the operational division, the financial division and the engineering division. Data collection was done by interviewing the staff on duty and making observations and observations while in the field. The data obtained is then analyzed and elaborated so as to form a relevant information. In addition to describing the results of interviews, there are some data that are processed using statistical analysis using correlation tests and simple linear regression tests. The statistical data analysis was used to determine the relationship between vehicle rental payments and operational activities and to find out what percentage of the effect was obtained from the two variables. The results of the correlation test using SPSS statistic 25 which shows that vehicle rental payments and operational activities have a positive relationship, the results of a simple linear regression test get the equation $Y=200534,257+0.659 X$. The value of $R$ square is 0.559 .

Keywords : Delay, Payment, Trucking

\section{ABSTRAK}

Penelitian ini bertujuan untuk dapat mengetahui penyebab dan dampak yang ditimbulkan akibat adanya keterlambatan pembayaran sewa kendaraan trucking di Perum DAMRI Logistik khususnya terhadap kegiatan operasional perusahaan. Pengambilan data dilakukan pada 3 divisi yang berada di Perum DAMRI Logistik yaitu divisi operasional, divisi keuangan dan divisi teknik. Pengambilan data dilakukan dengan cara wawancara kepada staf - staf yang sedang bertugas serta melakukan pengamatan dan observasi ketika berada di lapangan. Data yang diperoleh kemudian dianalisis dan dijabarkan sehingga membentuk sebuah informasi yang relevan. Data yang diolah menggunakan analisis statistik dengan menggunakan uji korelasi dan uji regresi linier sederhana. Analisis data statistik tersebut digunakan untuk mengetahui hubungan antara pembayaran sewa kendaraan dengan kegiatan operasional dan mengetahui berapa persen pengaruh yang diperoleh dari kedua variabel tersebut. Hasil uji korelasi menggunakan SPSS statistic 25 yang menunjukkan bahwa pembayaran sewa kendaraan dan kegiatan operasional memiliki hubungan postitif, hasil uji regresi linier sederhana didapatkan rumus persamaan $\mathrm{Y}=200534,257+0,659 X$. Nilai $\mathrm{R}$ square sebesar 0,559.

Kata kunci : Keterlambatan, Pembayaran, Trucking 


\section{A. Pendahuluan}

Perkembangan logistik dalam negeri telah mengalami kemajuan yang cukup cepat. Hal ini terlihat dari adanya pertumbuhan yang sangat signifikan dalam kegiatan usaha logistik seperti pendistribusian barang dan pergudangan. Bersamaan dengan perkembangan kemajuan dalam dunia logistik, perusahaan harus mampu bekerja secara efektif dan efisien dalam segala hal agar dapat meningkatkan kualitas pelayanan yang lebih baik sepanjang harinya. Hal ini akan mempengaruhi kemampuan perusahaan dalam mengelola dan mengawasi bidang usaha yang ada agar dapat meningkatkan persentase penjualan yang lebih tinggi di Indonesia. (Suyadi S \& Aryananda Anugrah Muhamad, 2019)

Transportasi darat pengangkut barang atau logistik memiliki perbedaan dengan transportasi darat pengangkut penumpang, dimana transportasi darat yang digunakan sebagai pengangkut barang membutuhkan biaya operasional untuk melakukan kegiatan pengiriman barang terlebih dahulu dan akan menerima pembayaran atas sewa yang telah diberikan sesuai dengan kesepakatan yang telah ditentukan pada awal sebelum proses order diterima. Sedangkan transportasi darat pengangkut penumpang pada umumnya akan langsung menerima pembayaran hasil sewa nya ketika penumpang telah sampai pada tempat yang dituju. Biaya operasional yang dikeluarkan harus seimbang dengan pendapatan hasil sewa yang akan diperoleh dalam jasa pengiriman barang tersebut. Perputaran antara pendapatan dan pengeluaran biaya operasional tersebut harus dikelola dengan baik untuk tetap menjaga kualitas pelayanan yang akan diberikan kepada costumer.

Untuk mencapai kualitas terbaik yang diinginkan, perusahaan harus dapat mengelola biaya operasional yang dikeluarkan dengan pendapatan yang diterima dari hasil sewa kendaraan tersebut dengan baik. Pada kenyataanya, sering terjadi permasalahan di bidang operasional yang ditenggarai sebagai akibat keterlambatan penerimaan biaya yang dibutuhkan untuk operasional pengiriman barang. Apabila hal tersebut terus terjadi dan tidak dapat segera diperbaiki maka dampak-dampak yang terjadi akibat keterlambatan pembayaran tersebut dapat berakibat tidak baik bagi penyedia ataupun penyewa jasa.

\section{B. Metode Penelitian}

Dalam penelitian ini, metode yang digunakan oleh penulis yaitu metode kuantitatif. Metode kuantitatif merupakan 
suatu cara yang digunakan untuk menjawab masalah penelitian yang berkaitan dengan data yang berupa angka dan menggunakan instrumen program statistik. Untuk pengolahan data menggunakan rekapitulasi data keuangan yang didapatkan dari perusahaan tempat melakukan penelitian. Kemudian diinput menggunakan program SPSS dan output dari hasil olah data tersebut dijabarkan menggunakan kata-kata agar dapat mudah untuk dipahami. Kemudian untuk mendukung penelitian tersebut beberapa kajian literatur berupa jurnal, buku dan arsip dokumen, rekapan hasil wawancara dan dokumentasidokumentasi yang didapatkan bisa memperkuat hasil yang diperoleh dari penjabaran penulisan tugas akhir ini.

\section{Hasil dan Pembahasan}

Setiap perusahaan memerlukan distribusi yang dapat melakukan suatu proses kegiatan pemasaran sehingga mempermudah penyaluran barang atau jasa. Untuk menciptakan distribusi yang baik maka perusahaan harus memiliki fasilitas dan alur proses kegiatan yang tersusun dengan baik. (Anggadha Pratama \& Mulyono, 2019) proses pendistribusian barang menggunakan jalur darat terutama dengan menggunakan kendaraan trucking masih menjadi pilihan utama bagi costumer untuk melakukan pengiriman barang dalam jumlah banyak. Setiap perusahaan yang begerak dibidang ekspedisi khususnya penyewaan kendaraan trucking pasti memiliki standar proses untuk penyewaan kendaraannya yang berbeda sesuai dengan kebijakan dibuat oleh perusahaan.

\section{Proses Alur Penyewaan Kendaraan Trucking}

Perum DAMRI Logistik memiliki sebuah alur penyewaan kendaraan trucking kepada costumer sesuai dengan standar operasional yang ditelah diterapkan di lapangan untuk mengatur jalannya kelancaran proses penyewaan kendaraan trucking.

Prosedur tersebut harus ditaati oleh seluruh pegawai baik itu staf administrasi maupun sopir yang bertugas untuk melakukan pengiriman barang. Dengan adanya prosedur aturan pengiriman barang tersebut dapat meminimalisir kesalahan yang terjadi di lapangan apalagi sampai menimbulkan kerugian.

Mekanisme Pembayaran Penggunaan Jasa Kendaraan Trucking

Mekanisme pembayaran dilakukan dengan menggunakan data jumlah order yang telah direkap kedalam beberapa invoice yang berbeda. Rekapan invoice yang akan dikirimkan kepada costumer setiap bulan memiliki jumlah order yang berbeda. Pembuatan invoice atas sewa jasa 
kendaraan trucking di Perum DAMRI

Logistik tidak lagi akan sesuai berdasarkan tanggal dimulainya order akan tetapi dibuat dan direkap pada lembar invoice tergantung pada jarak kota pengiriman yang dituju atau dengan kata lain direkap berdasarkan surat jalan yang telah kembali ke Perum DAMRI Logistik setelah selesai melakukan pengiriman barang.

Berdasarkan rincian dari rekapan pembayaran milik PT. Tiga Pilar hanya pada bulan Desember 2020 dan bulan Januari 2021. Total keseluruhan jumlah tagihan yang telah dibuatkan invoice dan harus dibayarkan oleh PT. Tiga Pilar pada bulan Desember 2020 dan bulan Januari 2021 adalah sebanyak Rp. 99.328.000 namun dari hasil data keuangan yang diperoleh pada tanggal 10 Februari 2021 hanya Rp. 56.237.000 yang telah dibayarkan dan dengan waktu pembayaran yang melebihi batas waktu yang telah ditentukan.

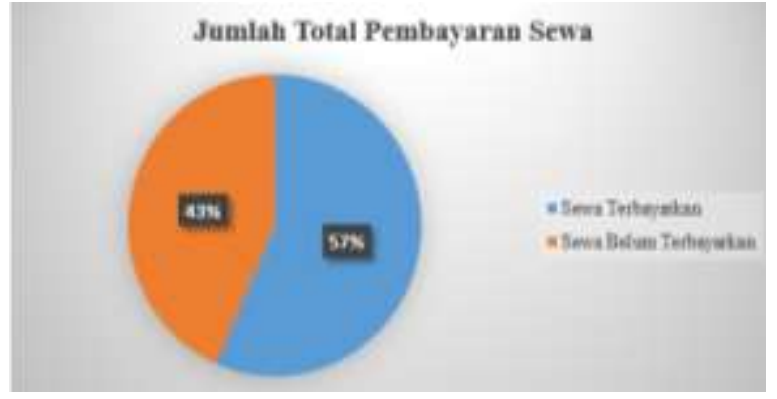

Gambar 1. Presentase Jumlah Pembayaran Sewa Kendaraan

Sumber: Dokumen keuangan, 2021
Dari hasil data presentase biaya sewa yang terbayarkan selama bulan Desember 2020 dan bulan Januari 2021 hanya sebanyak $57 \%$ dan jumlah biaya sewa yang belum terbayarkan pada bulan tersebut yaitu sebanyak $43 \%$ dari total keseluruhan biaya sewa yang harus terbayarkan.

\section{Penyebab Keterlambatan Pembayaran}

\section{Sewa Kendaraan Trucking}

Keterlambatan pembayaran sewa kendaraan trucking yang terjadi di Perum DAMRI Logistik memiliki sebab-sebab yang terjadi dikarenakan adanya kondisi pelaksanaan yang tidak sesuai dengan yang diharapkan. Berikut akan dijelaskan beberapa hal yang dapat menyebabkan keterlambatan pembayaran sewa kendaraan trucking di Perum DAMRI Logistik:

a. Hilangnya Bukti Surat Jalan

Surat jalan dalam proses pengiriman barang merupakan suatu dokumen wajib yang harus dibawa oleh pengemudi dalam melaksanakan proses pengiriman barang hingga barang tersebut sampai kepada tempat tujuan pengiriman.

Perum DAMRI Logistik menggunakan bukti surat jalan setelah selesai pengiriman ke tempat tujuan pengiriman, sebagai bukti kuat penagihan yang juga dilampirkan pada lembar invoice yang selanjutnya akan 
dikirimkan kepada costumer. Surat jalan yang dilampirkan pada lembar invoice harus berupa surat jalan asli yang bertanda tangan dan berstampel dari petugas gudang yang memiliki hak dalam penerimaan barang yang telah selesai dibongkar pada tempat tujuan pengiriman barang.

Surat jalan asli merupakan dokumen wajib yang harus dilampirkan sebagai bukti kuat dalam penagihan atas sewa kendaraan yang telah dilakukan oleh costumer. Maka pengemudi harus berhati-hati dan dapat mengembalikan surat jalan tersebut kepada divisi operasional untuk selanjutnya dilakukan pembuatan invoice. Namun, dikarenakan adanya kelalaian pada pelaksanaan di lapangan yang pada akhirnya menyebabkan surat jalan asli tersebut hilang. Hal yang paling sering menyebabkan surat jalan hilang biasanya yaitu terjadi kesalahan komunikasi antara pengemudi dan staf operasional, surat jalan tercampur dengan berkas lainnya dan lupa tempat meletakkan surat jalan serta banyak hal-hal lainnya yang menyebabkan surat jalan tersebut kemudian hilang dan tidak dapat temukan.
Tabel 1. Jumlah kehilangan Surat Jalan

\begin{tabular}{|c|c|c|c|c|}
\hline \multirow[t]{2}{*}{ NO } & \multirow{2}{*}{$\begin{array}{c}\text { Tanggal } \\
\text { Kehilangan }\end{array}$} & \multicolumn{2}{|c|}{$\begin{array}{c}\text { Jumlah Kehilangan } \\
\text { di Bulan }\end{array}$} & Jum \\
\hline & & Des & Jan & \\
\hline 1 & $3 / 12 / 2020$ & 1 & & 1 \\
\hline 2 & $27 / 01 / 2021$ & & 1 & 1 \\
\hline
\end{tabular}

Sumber: Arsip dokumen Divisi Operasional Berdasarkan tabel 3.5 dapat dilihat jumlah data kehilangan surat jalan yang terjadi di bulan Desember 2020 dan Januari 2021 milik PT. Tiga Pilar menunjukan dalam 2 bulan terdapat 2 kasus kehilangan surat jalan yang membutuhkan waktu berkisar antara 7 sampai 10 hari untuk melakukan proses pengurusan ulang surat jalan yang hilang agar dapat pengganti surat jalan baru tanpa merubah apapun dari surat jalan yang hilang.

Ketika hal itu terjadi, maka proses pembuatan invoice penagihan kepada costumer pun akan terhambat. Dan membutuhkan waktu yang cukup lama untuk mengurus kembali surat jalan tersebut sesuai dengan prosedur awal pengiriman barang. Sebelum proses pembuatan ulang surat jalan selesai maka pembuatan invoice untuk penagihan ke costumer pun akan terhambat pula dan akan berdampak selanjutnya kepada pembayaran sewa yang seharusnya diterima oleh Perum DAMRI Logistik.

b. Kurang peraturan terkait mekanisme pembayaran 
Mengenai peraturan mekanisme pembayaran di Perum DAMRI Logistik, hingga saat ini tidak ada peraturan yang mengikat dan sanksi yang tegas untuk mekanisme pembayaran atas jasa penyewaan kendaraan trucking, untuk pembayaran biasanya hanya tercantum pada perjanjian kerjasama diawal saat costumer menghubungi Perum DAMRI Logistik untuk menyewa kendaraan. Pada saat itu kedua belah pihak akan mengajukan nego terkait mekanisme pembayaran dengan rentang waktu 15 hari, 30 hari atau 40 hari setelah proses pengiriman barang selesai. Namun, keputusan terkait pembayaran tetap diberikan kepada pihak costumer dan pihak dari Perum DAMRI Logistik sendiri tidak memiliki aturan terkait mekanisme pembayaran atas penyewaan kendaraan trucking.

Hal tersebut yang menyebabkan seringnya terjadi keterlambatan pembayaran, dengan tidak adanya sanksi yang tegas dan peraturan yang mengikat, costumer dapat melakukan pembayaran hingga melewati batas waktu yang telah ditentukan bersama pada awal melakukan kerjasama.

Keterlambatan pembayaran yang melebihi batas waktu yang telah ditentukan akan membuat pendapatan sewa tidak sesuai dengan biaya operasional yang harus dikeluarkan kembali untuk memberikan pelayanan kepada perusahaan tersebut. Pihak dari Perum DAMRI Logistik tidak dapat melakukan hal apapun selain mencoba menghubungi costumer perusahaan terkait melalui e-mail atau telepon untuk mengingatkan kembali bahwa pembayaran atas sewa kendaraan telah melewati batas waktu yang telah ditetapkan.

\section{Analisis Hubungan Antara Pembayaran}

\section{Sewa dengan Kegiatan Operasional}

Agar dapat mengetahui apakah pembayaran sewa memiliki hubungan dengan kegiatan operasional. Perlu dilakukan uji yang dapat membuktikan bahwa variabel bebas (biaya sewa) dengan variabel terikat (biaya operasional) tersebut saling berkaitan. Dengan menggunakan data yang diperoleh dari divisi operasional yaitu rekapitulasi biaya sewa yang harus dibayarkan dan biaya kegiatan operasional yang harus dikeluarkan. Model analisis yang digunakan untuk mendapatkan hasil tersebut yaitu analisis uji korelasi person dan analisis regresi linier sederhana.

a. Analisis uji korelasi person

Uji korelasi bertujuan untuk mengetahui tingkat keeratan hubungan 
antara variabel yang dinyatakan dengan koefisien korelasi $(r)$. Melalui uji korelasi person dapat diketahui bentuk hubungan antara kedua variabel, apakah kedua variabel tersebut bersifat positif atau negatif.

Untuk pengambilan sebuah keputusan dari uji korelasi person dapat dilihat melalui:

1. Apabila nilai dari signifikasi $<0,05$ maka dapat dikatakan hubungan tersebut saling berkorelasi

2. Apabila nilai dari signifikasi > 0,05 maka dapat dikatakan hubungan tersebut tidak saling berkorelasi

Interpretasi dari sebuah koefisien korelasi dapat dilihat pada tabel sebagai berikut:

Tabel 2. Interpretasi Koefisien Korelasi

\begin{tabular}{|c|c|}
\hline $\begin{array}{l}\text { Interval } \\
\text { koefisien }\end{array}$ & Tingkat Hubungan \\
\hline $0,800-1,000$ & $\begin{array}{c}\text { Hubungan korelasi sempurna } \\
\text { (Sangat Kuat) }\end{array}$ \\
\hline $0,600-0,800$ & Kuat (Korelasi Kuat) \\
\hline $0,400-0,600$ & $\begin{array}{l}\text { Cukup (hubungan korelasi } \\
\text { sedang) }\end{array}$ \\
\hline $0,200-0,400$ & Rendah (Korelasi lemah) \\
\hline $0.000-0,100$ & $\begin{array}{c}\text { Sangat rendah } \\
\text { korelasi) }\end{array}$ \\
\hline
\end{tabular}

Sumber: Jurnal Sipil Statik (Bertan et al., 2016)
Berdasarkan hasil dari pengambilan dasar keputusan dan melihat hasil dari interprtasi koefisien korelasi maka akan dapat disimpulkan apakah antara kedua variabel yang diuji memiliki sebuah hubungan korelasi yang saling berkaitan dan seberapa kuat hubungan korelasi antara kedua varibel tersebut.

\section{Tabel 3. Hasil Uji Correlations}

\section{Correlations}

\begin{tabular}{|c|c|c|c|}
\hline & & $\begin{array}{c}\text { Biaya } \\
\text { sew } \\
\text { a }\end{array}$ & $\begin{array}{l}\text { Biaya } \\
\text { Operasi } \\
\text { onal }\end{array}$ \\
\hline \multirow[t]{3}{*}{ Biaya sewa } & $\begin{array}{l}\text { Pearson } \\
\text { Correlati } \\
\text { on }\end{array}$ & 1 & $.748^{* *}$ \\
\hline & Sig. (2-tailed) & & .000 \\
\hline & $\mathrm{N}$ & 56 & 56 \\
\hline \multirow{4}{*}{$\begin{array}{l}\text { Biaya } \\
\text { Operasio } \\
\text { nal }\end{array}$} & Pearson & $.748^{* *}$ & 1 \\
\hline & $\begin{array}{l}\text { Correlati } \\
\text { on }\end{array}$ & & \\
\hline & Sig. (2-tailed) & .000 & \\
\hline & $\mathrm{N}$ & 56 & 56 \\
\hline
\end{tabular}

Sumber: Output data SPSS 25

Dapat disimpulkan pada tabel diatas bahwa nilai signifikasi dari uji korelasi person biaya sewa memiliki nilai 0,000 dan biaya operasional memiliki signifikasi 0,000 yang dapat artinya nilai signifikasi kedua variabel tersebut $<0,05$ yang dapat disimpulkan bahwa kedua variabel tersebut memiliki hubungan/berkorelasi. Dari tabel tersebut dapat diketahui pula pearson 
correlation dari biaya sewa adalah 0,748 dan untuk biaya operasional memiliki nilai 0,748 yang berarti kedua variabel tersebut memiliki hubungan positif.

Jika dilihat dari nilai pearson correlation kedua variabel 0,748 yang berarti antara variabel tersebut berkorelasi yang sangat kuat dan memiliki hubungan positif dikarenakan nilai 0,748 berada pada rentang nilai interval koefisien 0,600 - 0,800 yang berarti hubungan tersebut memiliki hubungan korelasi yang sangat kuat dan dinyatakan bersifat positif karena nilai akhir setelah dilakukan uji terhadap kedua variabel tersebut memiliki hasil yang bernilai positif. Yang dimaksud memiliki hubungan positif yaitu semakin tinggi biaya sewa yang didapatkan maka semakin tinggi pula kemampuan perusahaan dalam memaksimalkan biaya operasional nya. Begitu juga sebaliknya apabila biaya sewa yang diperoleh semakin rendah maka semakin rendah pula kemampuan perusahaan untuk memenuhi biaya operasionalnya.

Jadi, dapat disimpulkan melalui uji korelasi semakin tinggi jumlah pembayaran sewa maka semakin tinggi pula kemampuan perusahaan untuk dapat memaksimalkan biaya operasional.

b. Analisis uji regresi linear sederhana

Analisis regresi linear sederhana digunakan untuk menguji atau memprediksi pengaruh satu variabel bebas dengan variabel terikat.

Pengambilan keputusan dalam uji regresi linear sederhana dapat mengacu pada dua hal yaitu

1. Apabila nilai signifikasi $<0,05$ artinya variabel $\mathrm{x}$ berpengaruh terhadap variabel y

2. Apabila nilai signifikasi $>0,05$ artinya variabel $\mathrm{x}$ tidak berpengaruh terhadap variabel y

Regresi linier sederhana dianalisa berdasarkan hubungan sebab akibat yang ditimbulkan oleh variabel terikat (y) terhadap variabel bebas (x) yang kemudian akan didapatkan sebuah rumus persamaan garis regresi linier sederhana sebagai berikut:

$$
\mathrm{Y}=\mathrm{a}+\mathrm{bX}
$$

Keterangan:

$\mathrm{a}=$ konstanta yang menyatakan nilai $\mathrm{Y}$ apabila $X=0$

$\mathrm{b}=$ koefisien regresi atau taksiran dari nilai $\mathrm{Y}$ apabila nilai $\mathrm{X}$ berubah $\mathrm{Y}=$ variabel yang dipengaruhi nilainya oleh variabel lainnya 
$\mathrm{X}=$ variabel yang memiliki pengaruh untuk variabel lainnya (Nuryadi et al., 2017)

\section{Tabel 4. Hasil Analisis Regresi Linier Sederhana}

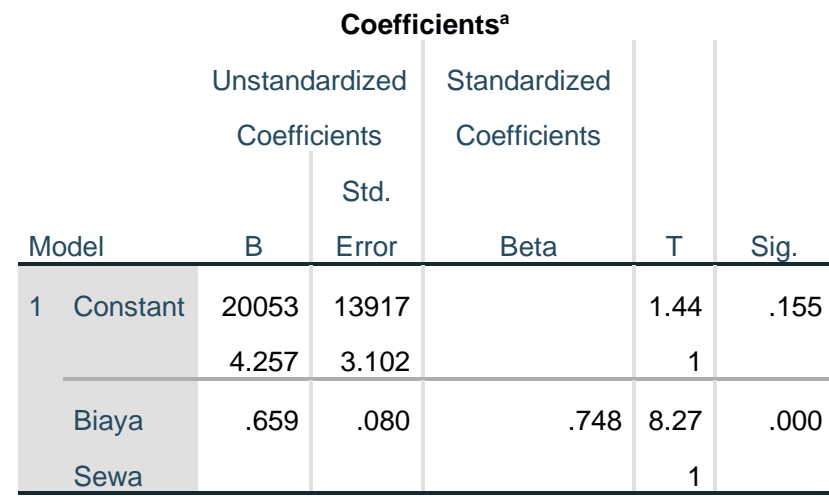

a. Dependent Variable: Biaya Operasional

Sumber: Output data SPSS 25

Dilihat dari tabel 3.9 dapat disusun persamaan regresi linier sederhana seperti:

$\mathrm{Y}=200534,257+0,659 \mathrm{X}$

Keterangan:

$\mathrm{Y}=$ Biaya kegiatan Operasional

$\mathrm{X}=$ Biaya Sewa Kendaraan

Didapatkan hasil koefisien yang kemudian dikembangkan melalui dasar persamaan regresi linier sederhana yaitu:

a. Konstanta sebesar 200534,257 jika biaya sewa kendaraan tidak ada maka biaya kegiatan operasional sebesar 200534,257. Hal tersebut menunjukkan pengaruh positif variabel independen (biaya sewa kendaraan). Bila variabel independen naik atau berpengaruh dalam satu satuan, maka variabel dependen (biaya kegiatan operasional) akan terpenuhi. b. Koefisien regresi $\mathrm{X}$ sebesar 0,659 yang artinya setiap biaya sewa kendaraan mengalami kenaikan maka akan mampu menaikan biaya kegiatan operasional sebesar 0,659 (Lesly \& Yuliadi, 2020)

\section{Tabel 5. Hasil Uji Statistik f}

\begin{tabular}{lc|r|r|r|r}
\multicolumn{7}{c}{ ANOVA $^{\text {Sa }}$} & \multicolumn{1}{l}{} \\
Model & Squares of & Df & Square & F & Sig. \\
\hline 1 Regressi & 63374343 & 1 & 6337434 & 68.402 & $.000^{\mathrm{b}}$ \\
& 7334.210 & & 37334.2 & & \\
& & & 10 & & \\
\hline Residual & 50030930 & 54 & 9264987 & & \\
& 0487.219 & & 046.060 & & \\
\hline Total & 11340527 & 55 & & & \\
& 37821.429 & & & & \\
\hline
\end{tabular}

a. Dependent Variable: Biaya Operasional

b. Predictors: (Constant), Biaya Sewa

Sumber: Output data SPSS 25

Menurut tabel tersebut diketahui bahwa nilai $\mathrm{F}$ hitung $=68.402$ dengan tingkat signifikasi sebesar $0,000<0,05$ yang berarti ada pengaruh dari variabel biaya sewa $(\mathrm{x})$ terhadap variabel biaya operasional $(\mathrm{y})$

\section{Tabel 6. Hasil Uji Koefisien Determinan $\left(\mathbf{R}^{2}\right)$}

\begin{tabular}{ll|l|l|r} 
& & & \multicolumn{3}{c}{ Model Summary } \\
Model & R & R Square & $\begin{array}{c}\text { Adjusted R } \\
\text { Square }\end{array}$ & $\begin{array}{c}\text { Std. Error of } \\
\text { the Estimate }\end{array}$ \\
\hline 1 & $.748^{\mathrm{a}}$ & .559 & .551 & 96254.803 \\
\hline
\end{tabular}

a. Predictors: (Constant), Biaya Sewa

b. Dependent Variabel : Biaya Operasional

Sumber: Output data SPSS 25 
Hasil output dari tabel tersebut yaitu diperolehnya koefisien determinasi ( $R$ Square) sebesar 0,559. Koefisien determinasi (R Square) didapatkan melalui hasil pengkuadratan nilai koefisien korelasi atau "R" yang dapat dilihat pada tabel 3.12 yaitu $0,748 \times 0,748=0,559$. Besar nya nilai koefisien determinasi ( $\mathrm{R}$ Square) adalah 0,559 atau sama dengan 55,9\% yang berarti bahwa pengaruh variabel bebas (biaya sewa) terhadap variabel terikat (biaya operasional) adalah $55,9 \%$ atau dapat disimpulkan pembayaran biaya sewa kendaraan memiliki pengaruh sebesar $55,9 \%$ untuk biaya kegiatan operasional yang dibutuhkan. Jadi, apabila biaya sewa terhambat akan otomatis berdampak pada biaya kegiatan operasional. Sedangkan $44,1 \%$ variabel terikat (biaya operasional) dipengaruhi oleh hal lain di luar variabel bebas (biaya sewa) atau dapat diartikan sebesar $44,1 \%$ biaya kegiatan operasional dipengaruhi oleh kegiatan lain di luar dari kegiatan penelitian. (Wulansari \& Azlina, 2018).

Pengaruh yang Terjadi Akibat Adanya Keterlambatan Pembayaran Atas Sewa

\section{Kendaraan}

Adanya keterlambatan pembayaran sewa kendaraan trucking yang terjadi di Perum DAMRI Logistik akan dapat menyebabkan beberapa kegiatan operasional di lapangan menjadi tidak optimal. Beberapa kegiatan yang terkena pengaruh dari keterlambatan pembayaran sewa tersebut adalah:

a. Kegiatan Operasional Usaha /Pemberangkatan Kendaraan

Marketing atau kegiatan memasarkan kendaran trucking kepada calon costumer merupakan salah satu kegiatan yang ada pada kegiatan operasional usaha.

Biaya operasional usaha dibutuhkan untuk mendukung perjalanan kendaraan trucking selama melakukan proses pengiriman barang. Biaya operasional ini dikelola dan dianggarkan oleh Perum DAMRI Logistik dengan menggunakan pendapatan keuangan yang diperoleh dari hasil sewa kendaraan yang didapat.

Tabel 7. Biaya Operasional Usaha

\begin{tabular}{|c|c|}
\hline No & Biaya Operasional Usaha \\
\hline 1 & Bahan Bakar Minyak \\
\hline 2 & Tol \\
\hline 3 & Uang Dinas Jalan (UDJ) \\
\hline 4 & Ferry \\
\hline 5 & Bongkar \\
\hline 6 & Muat \\
\hline
\end{tabular}

Sumber: Data diolah

Keterlambatan pembayaran sewa kendaraan akan berpengaruh pada biaya operasional yang harus 
dikeluarkan sedangkan biaya operasional usaha bersifat wajib untuk dikeluarkan sebagai penunjang kegiatan pengiriman barang. Dengan adanya keterlambatan pembayaran sewa kendaraan trucking tersebut, menjadikan perusahaan harus dapat mengelola keuangan dengan baik melalui hasil pembayaran sewa sebelumnya yang telah diterima agar dapat memenuhi permintaan order costumer selanjutnya.

b. Kegiatan Perbaikan Kendaraan Trucking

Kegiatan perbaikan dan pemeliharaan kendaraan dilakukan untuk tetap menjadi kualitas performa dari kendaraan trucking. Hal tersebut dilakukan untuk memberikan pelayanan jasa pengiriman barang yang terbaik bagi costumer. Untuk dapat melakukan perbaikan kendaraan, divisi teknik harus dapat melakukan kerjasama yang baik dengan divisi keuangan. Karena untuk melakukan pembelian kebutuhan jenis sparepart penunjang kebutuhan perbaikan memerlukan biaya yang harus dikeluarkan.

$\begin{array}{rlr}\text { Namun } & \text { dengan adanya } \\ \text { keterlambatan } & \text { pembayara sewa }\end{array}$

yang sering terjadi maka kondisi pendapatan perusahaan pun sulit untuk di prediksi dan pada akhirnya berdampak pada kegiatan perbaikan kendaraan, dan sebagai solusinya adalah dari divisi teknik harus dapat dengan jeli memilah jenis kerusakan kendaraan dan memprioritaskan kebutuhan sparepart untuk kendaraan yang harus jalan melakukan pengiriman barang dan mengalami kerusakan yang sangat fatal.

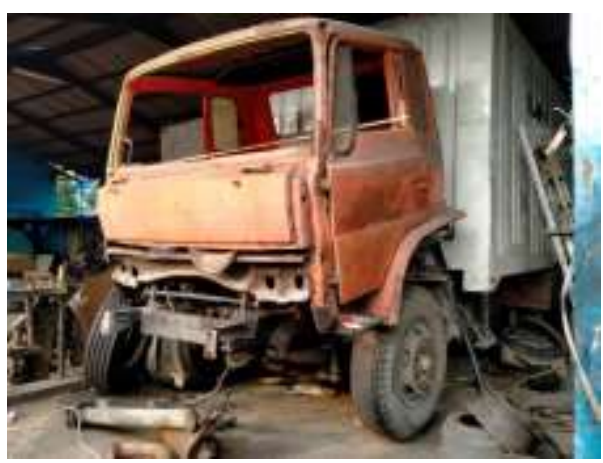

Gambar 2. Kendaraan Trucking

\section{Rusak Berat}

Sumber: Dokumentasi Pribadi

Kendaraan trucking milik Perum DAMRI Logistik yang mengalami rusak berat pada mesin kendaraan merupakan salah satu bentuk dari perbaikan yang kurang optimal sebelumnya yang kemudian untuk memperbaiki kendaraan tersebut memerlukan biaya perbaikan yang sangat besar selain 
itu kebutuhan sparepart yang sulit untuk di cari menjadi faktor harga jenis sparepart tersebut sangat mahal. Pada akhirnya kendaraan yang mengalami rusak berat dan tidak mungkin kembali dilakukan perbaikan dinyatakan tidak dapat berfungsi kembali untuk melakukan kegiatan operasional.

\section{Simpulan}

Berdasarkan analisis pengolahan data yang dilakukan mengenai dampak sistem pembayaran sewa kendaraan trucking terhadap kegiatan operasional Perum DAMRI Logistik, maka dapat disimpulkan sebagai berikut :

1. Penyebab keterlambatan pembayaran sewa kendaraan trucking ialah berkas bukti surat jalan selesai pengiriman hilang dan kurang nya peraturan terkait mekanisme pembayaran. Bukti surat jalan yang hilang akan memperlambat proses pembuatan tagihan kepada costumer dikarenakan harus melewati beberapa proses untuk mengganti surat jalan yang hilang.

Sedangkan untuk mekanisme pembayaran tidak ada peraturan yang tertulis secara terperinci dan konsekuensi atau sanksi yang tegas untuk sistem pembayaran antara

\section{costumer dengan Perum DAMRI logistik.}

2. Hubungan antara pembayaran sewa dengan kegiatan operasional memiliki hubungan positif atau kedua variabel tersebut dikatakan memiliki hubungan yang sangat kuat hal tersebut dibuktikan pada hasil uji korelasi. Untuk mengetahui tingkat persentase dari hubungan antara kedua variabel tersebut digunakan uji regresi linear sederhana yang mendapatkan hasil koefisien determinasi (R Square) sebesar 0,559 yang berarti pembayaran biaya sewa kendaraan memiliki pengaruh sebesar $55,9 \%$ untuk biaya kegiatan operasional yang dibutuhkan.

3. Keterlambatan pembayaran akan berdampak terhadap kegiatan operasional usaha dan kegiatan perbaikan kendaraan. Dengan adanya keterlambatan pembayaran tersebut maka kegiatan operasional di Perum DAMRI Logistik menjadi tidak optimal pelaksanaanya.

\section{E. Daftar Pustaka}

Anggadha Pratama, F., \& Mulyono, T. (2019). Kinerja Lapangan Penumpukan Stasiun Jakarta Gudang Pt Kereta Api Indonesia. Logistik, 12(2), 9. https://doi.org/10.21009/logistik.v12i 2.17646

Bertan, C. V., Dundu, A. K. T., \& Mandagi, 
R. J. M. (2016). Pengaruh Pendayagunaan Sumber Daya Manusia (Tenaga kerja) Terhadap Hasil Pekerjaan (Studi Kasus Perumahan Taman Mapanget Raya (Tamara). Jurnal Sipil Statik, 4(1), 15. https://ejournal.unsrat.ac.id/index.p hp/jss/article/view/10727/10309

Lesly, N., \& Yuliadi. (2020). Terhadap Laba Bersih Pada Perusahaan Konstruksi Di Bursa Efek Indonesia. 6.

Nuryadi, Astuti, T. D., Utami, E. S., \& Budiantara, M. (2017). DasarDasar Statistika Penelitian. http://lppm.mercubuanayogya.ac.id/wpcontent/uploads/2017/05/BukuAjar_Dasar-Dasar-StatistikPenelitian.pdf

Perum DAMRI Logistik. (n.d.). CompanyProfile-DAMLOG.pdf (pp. 1-12).

Suyadi S, D., \& Aryananda Anugrah Muhamad. (2019). Analisa Faktor Fasilitas Menjadi Penyebab Terlambatnya Pengiriman Barang Dalam Kegiatan Delivery Di Gudang I Pt. Bhanda Ghara Reksa. Logistik, 12(1), 7-9. https://doi.org/10.21009/logistik.v12i 1.13711

Wulansari, M., \& Azlina, Y. (2018). Analisis Hubungan Biaya Promosi Dengan Pendapatan Pada Pt. Bank Xyz. Jurnal Riset Manajemen Dan Bisnis (JRMB) Fakultas Ekonomi UNIAT, 3(1), 85-90. https://doi.org/10.36226/jrmb.v3i1.8 9 